Jelena Wen

130219086/B

\title{
DEVELOPMENT OF SMALL ENTERPRISES IN INDONESIA
}

Micro scale business also called SMEs or UMKM is an influential driver of the economy in Indonesia, especially during this pandemic, many SMEs are growing and become one of the types of economy that many Indonesians are interested in running. Even though it is small, the economic turnaround that occurs is quite large and fast so that it can stir up the Indonesian economy. It is noted that the contribution of SMEs to the national economy is $60 \%$ of the gross domestic product (GDP), and due to the development of SMEs, $90 \%$ of the national workforce is absorbed. In addition to the influence on the internal state, the development of SMEs resulted in an increase in the export capacity of countries where Indonesia was able to export by $14 \%$.

The development is getting bigger and allows SMEs to survive for a long period of time, so various strategies are needed to maintain it in the midst of intense competition not only on a national scale, but also competition in exports with other countries. In addition, the development is also influenced by the area where SMEs develop, for example in East Java, most SMEs are in the form of food. In contrast to Bali or other areas that also sell disposable products such as household goods, and so on. Because of this diversity, as well as the increasing interest in building SMEs business, it is necessary for the excellence of every community to increase the development of the business. The development process can be carried out through several efforts, such as starting the use of digital, making continuous innovations in order to maintain the existence of businesses that have been run by the Indonesian people. The use of technology is now one of the developments carried out by business enterprises, such as from a data and information search system containing consumer interests, product innovation ideas, and so on. But now the use of technology can also facilitate the sales process because current payments use technology systems such as QRIS and payments through several applications and transfers so that the transaction process becomes faster. The right use of technology can also help sales of products or food offered by SMEs through social media and other internet so that they are easily accessible by the wider community. 
Before exploring business development, it is important to know the SWOT of the SMEs business. According to Tayibnapis and Setyaningrum (2016), SMEs have a strength, namely flexibility. Where the SMEs business has high resilience in adapting to changes or market developments. It is easy for SMEs to innovate and sell and offer new products. In addition, because the population of Indonesia, especially in the Java area, is large, the number of available workers is also large. In addition to the strength aspect, one must also understand the weaknesses of SMEs, which include limited capital and lack of banking access, so that sometimes demand services do not occur smoothly. In addition, the weakness also lies in the technological capabilities of the Indonesian people which are still low. This is a weakness in the quality and quantity of business facilities and infrastructure. The increasing number of SMEs actors, resulting in more and more newcomers to pursue this business. Thus, the competition is getting tougher and everyone's ways to win the competition are getting more diverse and sometimes unhealthy. SMEs in Indonesia also have limited access to suppliers as standard providers. As a result, products are also made with limited materials at high prices. However, the cost of suppliers in each region is different, usually in the central area the price of raw materials will be higher than in small areas.

In addition, according to Tayibnapis and Setyaningrum (2016), every SMEs has the opportunity to innovate and follow trends that are being favored by the community. So that business owners can also promote to a larger scope, this is supported by the high consumptive behavior of the Indonesian people. This is one of the factors that SMEs can survive in Indonesia even in a pandemic situation that results in an economic downturn. On the other hand, because of the pandemic, more and more people are innovating and applying their creativity in the form of opening small businesses. However, in addition to the opportunities that exist, small business actors always experience the threat of limited guarantees and recognition of the small businesses they run. In addition, there is a lack of funds or material assistance from the government to develop the business. Currently, it is also easier for a country to buy imported goods so that it can threaten the existence of domestic SMEs products.

However, according to Kemenkop-UKM(2020), during the pandemic, the development of SMEs became more focused because the government provided assistance and facilities for developing business ventures. Moreover, the government has also carried out several policies that encourage convenience for business actors by bearing Retail VAT, the government also bears BPJS health workers' contributions. In addition to the government, 
monetary, banking and fintech parties also provide incentives for invoice financing and supply chain financing, as well as carry out banking operational efficiency so that SMEs who carry out transactions can be carried out easily and quickly. The securities crowdfunding platform has also been improved. All of these policies are carried out in order to facilitate the turnover of SMEs business during the pandemic. Where imports are currently difficult to do, the existence of SMEs is an option for people to meet their needs and buy the products they need to meet their daily needs, especially in the midst of a pandemic that is difficult for people to access places.

\section{References}

Tayibnapis, A.Z. and Setyaningrum, Idfi. (2016). Strategi Pengembangan UKM Berbasis Inovasi di Provinsi Jawa Timur: Periode 2010-2014. Indonesia: Surabaya Univesity.

Bagus. 2021. "Perlu Rangsang Daya Beli Masyarakat”. Jawa Pos: Ekonomi Bisnis 29 April 2021. 